\title{
The role of maternal anti-A and anti-B antibody titers in predicting ABO hemolytic disease of the newborn
}

\author{
Nartono Kadri
}

\begin{abstract}
Abstrak
Telah dilakukan penelitian terhadap 268 persalinan ibu golongan darah O dengan bayinya golongan darah $A$ atau B. Kemampuan ibu golongan darah $O$ memproduksi antibodi anti-A dan anti-B tidak beda bermakna $(p<0,05)$. Ditemukan 94 bayi $(35,1 \%)$ mengalami ikterus potensial dan 174 bayi (64,9\%) ikterus tidak potensial. Untuk memprediksi kelahiran bayi ikterus potensial diperoleh titer antibodi anti-A dan anti-B $i b u \geq 1 / 256$ sebagai cul-off point dengan sensitifitas $83.33 \%$ dan spesifisitas $78,21 \%$, nilai prediksi positif $79,27 \%$ dan nilai prediksi negatif $17,57 \%$. Pada titer antibodi anti-A dan anti-B ibu $\geq 1 / 256$, risiko dilahirkannya bayi ikterus potensial secara bermakna menjadi 18 kali lebih besar dibandingkan titer $<1 / 256(R O 18,64 ; I K \quad 95 \%=6.18-56.18)$.
\end{abstract}

\begin{abstract}
A study has been conducted on 268 blood group $O$ delivering mothers and their related blood group $A$ and $B$ newborn infants. It revealed that the capability of mothers to produce anti-A and anti-B antibodies did not differ significantly from each other $(p>0.05)$. Ninety four (35.1\%) of the newborns developed potentional jaundice while the others did not. To predict the birth of a baby with potential jaundice, a maternal anti-A or anti-B antibody titer of $\geq 1 / 256$ was considered to be the cut-off point with a sensitivity and specificity of $83.33 \%$ and $78.21 \%$ respectively and a positive predictive value of $79.27 \%$ and a negative predictive value of $17.57 \%$. If the maternal anti-A or anti-B antibody titer was $\geq 1 / 256$ the risk for giving birth of a baby with potential jaundice rose significantly 18 times compared to those with titers of $<1 / 256($ OR 18,$64 ; C I 95 \%=6.18-56.18)$
\end{abstract}

Keywords: $A B O$ incompatibility, anti-A/B antibody titers, hemolytic disease of the newborn

$\mathrm{ABO}$ hemolytic disease of the newborn (ABO-HDN) is at present the most frequently hemolytic disease found in newborns after anti-Rh0 (anti-D) preventive measures againts Rhesus hemolytic disease have been found out. ${ }^{1,2} \mathrm{ABO}-\mathrm{HDN}$ is more frequently found in blood group A or B newborn infants born from blood group $\mathrm{O}$ mothers and the occurence significantly offers from $\mathrm{ABO}$ incompatibility cases in blood group $\mathrm{A}$ or $B$ mothers. ${ }^{1,2}$ This group represents the pregnancy at risk for $\mathrm{ABO}$ blood group incompatibility for the occurence of neonatal jaundice. This is actually caused by the fact that anti-A and anti-B antibodies of blood group $\mathrm{O}$ mothers is in general of IgG class origin which can pass transplacentally while in the case of blood group A or B mothers it is of IgM origin which can not pass across the placenta. ${ }^{3,4}$ Blood group $O$ mothers have naturally already anti-A and anti-B antibodies in their blood. The fetal red cells immunization across

Department of Child Health, Faculty of Medicine University of Indonesia/Dr. Cipto Mangunkusumo Hospital, Jakarta, Indonesia the placenta in $\mathrm{OA}$ or $\mathrm{OB}$ incompatible pregnancies may cause an immune response in the mother which may increase those levels of anti-A and anti-B antibody titers. Besides fetal red blood cell immunization, the level of the maternal anti- $\mathrm{A}$ and anti-B antibody titers depend also on the environment. The incidence of $\mathrm{ABO}-\mathrm{HDN}$ in slum areas is found to be higher than in favorable healthy living areas. ${ }^{5}$ This is thought to be as a consequence of the fact that in slum areas many E.coli bacteria and Ascaris lumbricoides worms are still prevailing while in those organism a substance resembling A or B red blood cell component is found. ${ }^{6,7}$ Continous and recurrent exposure may cause a secondary immune response thus resulting in the presence of anti-A and anti-B antibodies in the mother. In pregnant mothers with high titers of anti-A or anti-B antibodies, the risk for the newborn to contract $\mathrm{ABO}-\mathrm{HDN}$ becomes thus also higher., 8

The aim of this study is to find out the cutt-of point of the maternal anti-A and anti-B antibody titers which may function as a predictor in the occurence of potential jaundice in ABO-HDN. 


\section{MATERIALS AND METHODS}

The subjects of this study consisted of blood group $\mathrm{O}$ delivering mothers with their A or B blood group newborn infants. During pregnancy and labor the mothers had not received blood transfusion so far while the newborn infants were all live births which a birthweight of $>1500$ gram or gestation period of $>$ 32 weeks, all without mayor congenital malformations. Samples were patients from Dr.Cipto Mangunkusumo General Hospital, the Budi Kemuliaan Maternity hospital and also from four community health centers scattered all over Jakarta on April 1995 to January 1997. Maternal peripheral blood samples right before delivery were obtained and cord blood samples of the newborn infants after birth. Seroim- analysis were performed. To find out the anti-A and anti-B antibody titers as predictor of the occurrence of potential jaundice, a calculation was made on the sensitivity and specificity at the cut-off points of $1 / 64$, $1 / 128,1 / 256,1 / 512$ and $1 / 1024$ titers and plotted on the receiver operating characterstic (ROC) curve.

\section{RESULTS}

Two hundred sixty eight blood samples of the mother and of its respective newborn infants had been collected, consisting of blood group $\mathrm{O}$ mothers and cord blood group A or B of the newborn. The distribution of anti-A and anti-B antibody titers in the serum of the mother by the newborn's blood group is shown in Table 1.

Table 1. Maternal anti-A and anti-B antibody titers by the newborn's blood group

\begin{tabular}{crccc}
\hline \multirow{2}{*}{$\begin{array}{c}\text { Maternal anti-A and } \\
\text { anti-B antibody titers }\end{array}$} & \multicolumn{2}{c}{ Number of newborn } & $\begin{array}{c}\text { Number of } \\
\text { sample } \\
(\mathrm{n}=268)\end{array}$ & $\begin{array}{c}\text { Percentage } \\
(100.0 \%)\end{array}$ \\
\cline { 2 - 4 } & Blood group A & Blood group B & & 17.6 \\
$1 / 1-1 / 32$ & 21 & 26 & 111 & 41.5 \\
$1 / 64-1 / 128$ & 54 & 57 & 78 & 29.2 \\
$1 / 256-1 / 512$ & 34 & 44 & 29 & 0.9 \\
$1 / 1024-1 / 2048$ & 14 & 15 & 3 & 100 \\
\hline $1 / 2048$ & 1 & 2 & 268 & 100 \\
\hline
\end{tabular}

$x^{2}=0.32 ; \mathrm{df}=4 ; p=0.985 ; \mathrm{NS}$

munologic antiglobulin tests (Coombs' test) were performed in the mothers and newborns blood as soon as possible. The maternal anti-A and anti-B antibody titers were determined and the cord blood was divided into two groups, namely the potential jaundice (positive Coombs' test) and the non potential jaundice (negative Coombs' test). Design of the sudy were performed into two steps, the first step was a crosssectional study to obtain the basic data, while the second step was a case-control study (nested case-control study) between the potential jaundice and the non potential jaundice groups. To distinguish between the two groups as a case group and control group, a matching was done of three variables influencing the occurence of neonatal jaundice namely the gestation period, newborn blood group and the sex of the newborn. Data analysis was done with Chi-square test. Fisher's exact test with significance limit of $\mathrm{p}<0.05$ and by calculating relative risk (Odds ratio) with $95 \%$ confidence interval. Model of bivariat and multivariat
There was no significant difference found between the number of newborn with $\mathrm{A}$ and $\mathrm{B}$ blood group in any maternal titer group ( $p>0.05)$, meaning that the capability of blood group $\mathrm{O}$ mothers in producing anti-A or anti-B antibodies was the same.

Results of antiglobulin test of the newborn's cord blood were divided into the potential jaundice group (positive Coombs' test) and the non potential jaundice group (negative Coombs' test). Newborn with potential jaundice have the potential to develop neonatal jaundice. Table 2 shows the distribution of newborn blood group by the results of the antiglobulin tests.

As many as 94 out of the 268 studied samples (35.1\%)showed potential jaundice, those newborn had a tendency to develop neonatal jaundice. The probability of becoming potential jaundice in the blood group A or B newborn did not differ significantly ( $\mathrm{p}>$ 0.05 ). 
Table 2. Distribution of antiglobulint test by newborn's blood group

\begin{tabular}{lcccc}
\hline \multicolumn{1}{c}{ Antiglobulin test } & \multicolumn{2}{c}{ Number of newborn } & $\begin{array}{c}\text { Number of } \\
\text { sample } \\
(\mathrm{n}=268)\end{array}$ & $\begin{array}{c}\text { Percentage } \\
(100.0 \%)\end{array}$ \\
\cline { 2 - 3 } $\begin{array}{l}\text { Positive } \\
\text { (potential jaundice) }\end{array}$ & Blood group A & Blood group B & 94 & 35.1 \\
$\begin{array}{l}\text { Negative } \\
\text { (non potential jaundice) }\end{array}$ & 46 & 48 & 174 & 64.9 \\
\hline Total & 78 & 96 & 268 & 100 \\
\hline $\mathrm{x}^{2}=0.27 ; \mathrm{df}=1 ; \mathrm{p}=0.606 ; \mathrm{NS}$ & 124 & 144 & &
\end{tabular}

Table 3 reveals result of sensitifity and specificity tests on the various cut-off points of maternal blood group $O$ anti- $A$ and anti-B antibody titers which was then also plotted as a curve on the receiving operation characteristic (ROC) chart. percentage with a positive predictive value of $79.27 \%$ and negative predictive value of $17.57 \%$. With those sensitivity and specificity values the cut-off point of maternal anti-A and anti-B antibodies to be $1 / 256$. Plotting those sensitivity and specificity values on the

Table 3. Sensitivity and spesificity at various cut-off points of maternal anti-A and anti-B antibody titers

\begin{tabular}{ccccc} 
Maternal antibody titer & $\begin{array}{c}\text { Sensitivity } \\
(\%)\end{array}$ & $\begin{array}{c}\text { Specificity } \\
(\%)\end{array}$ & $\begin{array}{c}\text { Positive predictive value } \\
(\%)\end{array}$ & $\begin{array}{c}\text { Negative predictive value } \\
(\%)\end{array}$ \\
\hline $1 / 64$ & 100 & 23.08 & 56.52 & 0 \\
$1 / 128$ & 98.72 & 57.69 & 70 & 2.17 \\
$1 / 256$ & $\mathbf{8 3 . 3 3}$ & $\mathbf{7 8 . 2 1}$ & $\mathbf{7 9 . 2 7}$ & $\mathbf{1 7 . 5 7}$ \\
$1 / 512$ & 64.1 & 94.87 & 92.59 & 27.45 \\
$1 / 1024$ & 30.77 & 97.44 & 92.31 & 41.54 \\
\hline
\end{tabular}

At the maternal anti-A and anti-B antibody titer of $1 / 256$ it was found a sensitivity of $83.33 \%$ and a specificity of $78.21 \%$ which comprised the highest receiver operating charcteristic (ROC) chart a curve as follows will be seen (figure 1).

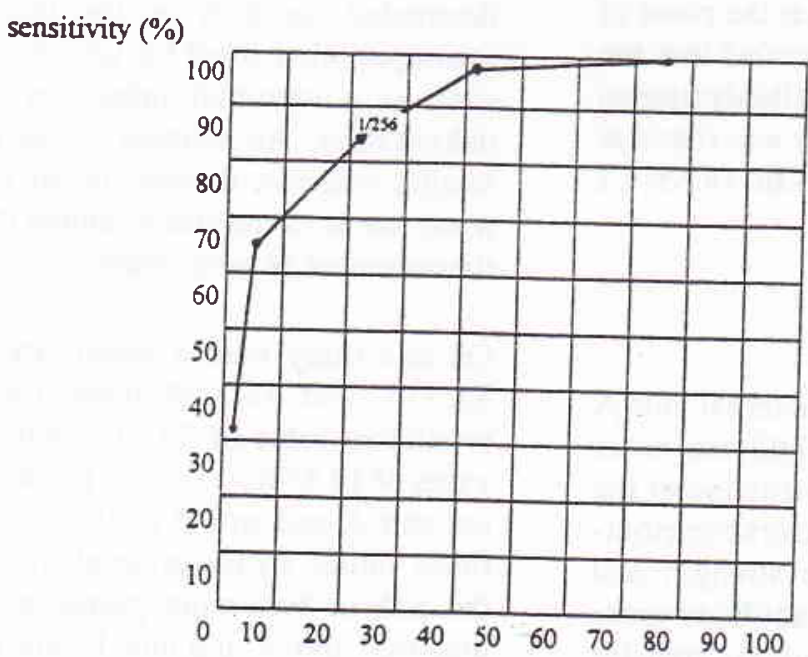

Figure 1. Receiver operating characteristic (ROC) curve 
One of the factor influencing the severity of $\mathrm{ABO}$ HDN is the strength and quantity of the mother's antibody cross transplacentally. ${ }^{10}$ After matching the potential jaundice and the nonpotential jaundice groups in the nested case-control methode (gestation period, blood group and sex), a total of 78 samples each respectively was taken for case group and control group.

Table 4 shows the bivariat analysis, the influence of maternal anti-A and anti-B antibody on the antiglobulin test at the cut-off point of $1 / 256$. the quantity and quality of the antibodies, several other factors may also contribute to the severity of ABO-HDN among others the antibody subclass, variation of antigen subtype of the fetal red blood cells, the secretor system of the fetal tissue and body fluid, the antibody quantity and speed transfer transplacentally, the efficiency of the fetal mononuclear cells and the maturity of the fetus. ${ }^{1,2,10,11,12}$ After 32 weeks of pregnancy the transplacental transfer of IgG antibody increases speedly and at the end of mature pregnancy the amount of IgG molecules in the placental

Table 4. Influence of maternal anti-A and anti-B antibody titer on potential jaundice

\begin{tabular}{lccc}
\hline $\begin{array}{l}\text { Maternal anti-A and } \\
\text { Anti-B titer }\end{array}$ & \multicolumn{2}{c}{ Antiglobulin test } & $\begin{array}{c}\text { Number of } \\
\text { sample } \\
\text { (n=268) }\end{array}$ \\
\cline { 2 - 4 } & $\begin{array}{c}\text { Positive } \\
\text { (potential jaundice) }\end{array}$ & $\begin{array}{c}\text { Negative } \\
\text { (non-potential jaundice) }\end{array}$ & \\
\hline $1 / 256$ & 65 & 17 & 82 \\
$<1 / 256$ & 13 & 61 & 74 \\
\hline Total & 78 & 78 & 156 \\
\hline
\end{tabular}

$\mathrm{x}^{2}=56.79 ; \mathrm{df}=1 ; \mathrm{p}=0.000 ;$ OR 17.94 CI $95 \%=7.52-43.77$

By the bivariat analysis it revealed that at the cut-off point of $1 / 256$ of the maternal anti-A and anti-B antibody titer the probability of the birth of a newborn with potential jaundice was significantly greater than titers of $<1 / 256$.

The multivariat analysis model was also performed on several other variables which on the bivariat analysis had a significant role on the occurence of potential jaundice namely placental inflammation, the way the baby was born and the facilities avaible at the place of birth. On the multivariat analysis it revealed that the influence of maternal anti-A or anti-B antibody titer on the occurence of potential jaundice baby was found at the cut-off point titer of $\geq 1 / 256$ with OR 18.65 ; CI $95 \%=6.18-56.18$.

\section{DISCUSSION}

In $\mathrm{ABO}$ incompatibility pregnancies, maternal anti- $\mathrm{A}$ and anti-B antibodies in the form of $\operatorname{IgG}$ can cross transplacentally and thus may cause destruction of the newborn's red blood cells. One of the factors contributing the severity of $\mathrm{ABO}-\mathrm{HDN}$ is the strength and quantity of maternal anti-A and anti-B antibody cross transplacentally. ${ }^{10}$ The higher the antibody transfer transplacentally the higher the probability of the destruction of the newborn's red blood cells. Besides trophoblast increases so that at birth the newborn infant's number of IgG molecules is higher than the mother's. ${ }^{13,14}$

To predict the occurence of potencial jaundice in $\mathrm{ABO}$ incompatible pregnancies it is important to know the cut-off point of the maternal anti-A and anti-B antibody titers so much so that monitoring action of the born baby can be intensified. The already sensitized red blood cells of the newborn can more easily be destructed not only on the fact of its condition of incompatibility itself but also because of other causes such as nosocomial infections, acidosis as well as dehydration. An increase of the bilirubin content following exessive destruction of red blood cells is already known to be able to hinder the baby's growth and development in later years. $15,16,17$

On this study with a sensitivity and a specificity of $83.33 \%$ and $78.21 \%$ respectively with a positive predictive value of $79,27 \%$ and a negative predictive value of $17.57 \%$, a cut-off point of $1 / 256$ of the maternal anti-A and anti-B antibody titer was found. With those values, by the bivariat analysis it was found that the risk of becoming potencial jaundice was at the maternal anti-A and anti-B antibody titer of $\geq 1 / 256$ with OR 17.94 ; CI $95 \%=6.18-56.18$. On the bivariat analysis there were still other possible variables work- 
ing synergically as well as antagonistically on the newborn's potential jaundice. After having performed a multivariat analysis on other variables contributing in the occurence of the newborn's potentional jaundice at that certain titer the ratio odds was OR 18.64; CI $95 \%=6.18-56.18$. The obtained data revealed that the titer of $\geq 1 / 256$ of the maternal anti-A and anti-B antibody the risk of the newborn infant with potential jaundice significantly became 18 times higher compared to those with low antibody titers $(<1 / 256)$.

This study was conducted on the middle to low sosio economic class comprising the mayor of our whole population. For clinical application it can be suggested that in a blood group $\mathrm{O}$ delivering mother with a non $O$ newborn infant, maternal anti- $A$ and anti- $B$ antibody titer $\geq 1 / 256$ on the antiglobulin test is a marker and warrant the health worker involved to intensify monitoring of the newborn infant. This is due to the fact that the risk for potential jaundice of the newborn becomes 18 times higher.

\section{Acknowledgements}

The author would like to express his sincere and heartfelt gratitude to all the midwives of the hospitals and health centers involved for helping in collecting the samples, to referral laboratory of the DKI Jaya Red Cross Blood Transfusion Service for the seroimmunologic examinations, to Drs Sudjadi for analyzing the data and to Dr. Titi S Sularyo for her cooperation in preparing the manuscirpt.

\section{REFERENCES}

1. Oski FA, Naiman JL. Hematologic problems in the newborn. 3rd ed. Philadelphia: Saunders; 1982. p. 283-346.

2. Nathan DG, Oski FA. Hematology of the infancy and childhood. 4th ed. Philadelphia: Saunders; 1993. p. 17-115, 495-674.

3. Abelson NM, Rawson AJ. Studies of blood group antibodies. V. Fractionation of examples of anti-B, anti-A,B,
anti-M, anti-P, anti-Jk ${ }^{\mathrm{a}}$, anti-Le ${ }^{\mathrm{a}}$, anti-D, anti-CD, anti-K, anti-Fy ${ }^{\mathrm{a}}$, anti-s and anti-Good. Transfusion 1961;1:116-23.

4. Rawson AJ, Abelson NM, Kochwa, et al. In: Bryant NJ, Ed. An introduction to immunohematology; 2nd ed. Philadelphia: Saunders; 1982. p. 197-200.

5. Huntley CC, Lyerly AD, Littlejohn MP, et al. ABO hemolytic disease in Puerto Rico and North Carolina. Pediatrics 1976; 95:875-83.

6. Oliver-Gonzales J. Functional antigens in helminths. J Infect Dis 1946;79:232-7.

7. Huntley CC, Lyerly AD, Patterson MV. Isohemagglutinins in parasitic infections. JAMA 1969; 208:1145-8.

8. Zipursky A. Isoimumne hemolytic diseases. In: Oski FA, Naiman JL. Eds. Hematologic problems in the newborn. 3rd ed. Philadelphia: Saunders; 1982.p.283-346.

9. Mollison PL. Blood transfusion in clinical medicine. In: Nathan DG, Oski FA, Eds. Hematology of the infancy and childhood. 3rd ed. Philadelphia: Saunders; 1993. p. 66-9.

10. Garraty GG. The serological investigation of hemolytic disease of the newborn. In: Sibanga CTHS, Das PC, Forfar JO, Eds. Pediatric and blood transfusion. The Hague: Martinus Nijhoff Publ; 1982. p. 4-21.

11. Bryant NJ. An introduction to immunohematology. 2nd ed. Philadelphia: Saunders; 1982. p. 28-207, 264-326.

12. Ukita M, Tkahashi A, Nunotani T, et al. IgG subclasses of anti-A and anti-B antibodies bound to the cord red cells in ABO incompatible pregnancies. Vox Sang 1989; 56:181-6.

13. Akin JW, Conover WB, DePriest PD. Increasing quantity of maternal immunoglobulin $\mathrm{G}$ in trophoblastic tissue before the onset of labour. Am J Obstet Gynecol 1990;162:1154-7.

14. Kohler PF, Farr RS. Elevation of cord over maternal IgG immunoglobulin: Evidence for an active placental IgG transport. Nature 1966; 1070-1.

15. Hendarto SK, Sutomenggolo TS, Ismael S, Monintja HE. Longterm follow-up study in infants with intermediate levels of neonatal hyperbilirubinemia. Pediatr Indon 1986; 26:8392.

16. Nakamura H, Takada S, Shimabuku RG. Auditory nerve and brainstem responses in newborn infants with hyperbilirubinemia. Pediatrics 1985; 75:703-8.

17. Kemper KJ, Forsyth BW, McCarthy PL. Persistent perceptions of vunerability following neonatal jaundice. Am J Dis Child 1990; 44:238-41. 